\title{
La judería de Xàtiva en la Edad Media
}

\author{
José Hinojosa Montalvo *
}

El judaísmo valenciano sufrió una notable macrocefalia en su desarrollo en el reino de Valencia, que no es sino un reflejo a menor escala de lo que acontecía en la sociedad cristiana: una cabeza visible, la judería de Valencia, el núcleo rector de este judaísmo, la más poblada y dinámica, y una serie de núcieos de mediano y pequeño tamaño, como las juderías de Morvedre (Sagunto), Xàtiva, Castellón, Villarreal, Burriana, Orihuela, etc., dispersas por todo el reino, en las que se plasma la red urbana y económica del país, así como la trayectoria histórica de la minoría hebrea, uno de los tres pilares sobre los que descansaba la sociedad valenciana del Medievo.

Estas juderías valencianas han tenido desigual fortuna historiográfica, como ya analicé en otra ocasión ". Hay bastantes noticias recopiladas y conocemos relativamente bien algunas épocas de la judería de Valencia, mientras que juderías como las de Morella ${ }^{2}$, Castellón de la Plana ${ }^{3}$, Burriana ${ }^{4}$, Villarreal ${ }^{5}$, Sagunto ${ }^{6}$, Alzira ${ }^{7}$, Elche ${ }^{8}$ u Orihuela ${ }^{9}$ han tenido sus

* Universidad de Alicante.

Hinojosa MONTALVo, J., «En torno a los judíos valencianos: la recuperación de una minoría olvidada», Hispania, L/2, n. ${ }^{175}, 1990$, págs. 921-940.

2 Grau Monserrat, M., "La judería de Morella (siglos XIII-XIV) ", Sefarad, n. ${ }^{\circ}$ XIV, 1954, págs. 247-264.

3 BaLbas, J. A., El libro de la provincia de Castellón. Castellón de la Plana 1892. Referencias a los judíos en las págs. 137-149. Magdalena Nom de DeU, J. R., La aljama hebrea de Castellón de la Plana en la Baja Edad Media. Castellón de la Plana 1978. Los judíos ante la "Cort del Justicia» de Castellón de la Plana (siglo xv). Castellón 1989.

4 Magdalena Nom de Deu, J. R., La judería de Burriana (siglos XIII-XIV). Burriana 1978.

5 Doñate Sebastia, J. M. ${ }^{\text {a }}$, «Les juderies de la Plana (Aportació al seu estudi)", Primer congrés d'Història del País Valencià, II. Valencia 1980, págs. 811-820. Doñate SebaStiA, J. y MAGDalena Nom DE Deu, Three Jewish Communities in the Medieval Kingdow of Valencia-Burriana, Castellón de la Plana, Villarreal. Jerusalem 1990.

' Chabret, A., Sagunto, su historia y sus monumentos. Barcelona 1898. PILES Ros, L., «La judería de Sagunto. Sus restos actuales", Sefarad, n. ${ }^{\circ}$ XVII, 1953, págs. 352-373.

7 PILES ROS, L., "Sobre los judíos de Alcira (Notas para su estudio)", Sefarad, n. ${ }^{\circ}$ XX, 1960, págs. $363-376$

8 Hinojosa Montalvo, J., "Los judíos de Elche durante la Baja Edad Media», Homenaje al doctor Juan Torres Fontes, 1. Murcia 1987, págs. 791-808. 
estudiosos, en función de las corrientes históricas del momento o de la existencia de un erudito local o investigador preocupado por las vicisitudes de esta minoría. Otras comunidades, en cambio, no han tenido la misma suerte y continúan envueltas en la bruma del pasado, como pueden ser Segorbe, Lliria o la misma Xàtiva, esta última objeto de nuestros estudio.

De los judíos en Xàtiva hay pocas noticias. El erudito $C$. Sarthou en su voluminosa obra Datos para la historia de Játiva ${ }^{10}$ no hace ninguna alusión a la presencia judía en la ciudad, por lo que ésta ha seguido siendo ignorada para los que manejaban estas fuentes impresas. Los datos había que buscarlos en los archivos. Es lo que hicieron Baer ${ }^{11}$, Burns ${ }^{12}$ o Romano ${ }^{13}$ en obras de carácter general, donde encontramos noticias aisladas sobre judíos en Xàtiva, pero siempre en el marco cronológico del siglo xill. Hay un solo trabajo monográfico sobre estos judíos, obra de A. Ventura, que intenta situar el emplazamiento de la judería, en base a diversas hipótesis, pero sin ningún soporte textual o arqueológi$\mathrm{co}^{14}$. Nuestro objetivo será intentar una primera aproximación al conocimiento de los judíos de Xàtiva, utilizando documentación específica, que para los siglos XIV y XV es inédita.

\section{EL SIGLO XIII ASENTAMIENTO Y CONSOLIDACIÓN DE LA ALJAMA SETABENSE}

El punto de partida de la aljama de Xàtiva en la Baja Edad Media es la conquista de la ciudad por Jaime I de Aragón en 1244. Xàtiva era desde época romana una importante plaza, gracias a su emplazamiento en el centro de una fértil comarca y en un nudo de comunicaciones, hacia las tierras del interior valenciano, Alicante, y hacia la meseta castellana. Una imponente fortaleza servía de control de los caminos y del territorio, así como para la defensa de sus habitantes. Estos factores geoestratégicos

\footnotetext{
9 VILAR, J. Bta., "La judería medieval de Orihuela (Alicante)», Boletín de la Asociación Española de Orientalistas, $\mathrm{n} .^{\circ} \mathrm{XIII}, 1977$, págs. 175-186.

10 Sarthou Carkeres, C., Datos para la Historia de Játiva. Játiva 1933.

11 BaER, Y., Historia de los judíos en la España cristiana, traducida del hebreo por J. L. Lacave. Madrid, Altalena, 1981.

12 Bunns, R. I., Moros, cristians i jueus en el regne croat de València. Valencia, Tres i Quatre, 1987.

13 Romano, D., Judíos al servicio de Pedro el Grande de Aragón (1276-1285). Barcelona 1983.

14 Ventura, A., "Possible localització de la jueria o call de Xàtiva», Xàtiva, fira d'agost, 1979, págs. 29-36.
} 
y comerciales, su carácter de frontera, cimentaron y aseguraron la fortuna de la ciudad hasta nuestros días. No es extraño, por tanto, que la comunidad hebrea decidiera instalarse en ella. $O$ continuar una vieja tradición secular, pues nada sabemos de los judíos en Xàtiva durante la etapa musulmana.

La noticia más antigua que relaciona a los judíos con Xàtiva es la participación de Bahye (Bahiel) Alconstantini, secretario de asuntos árabes de la Corona, en las negociaciones de la rendición de Xàtiva. También estuvo en las de Mallorca y Murcia. Su conocimiento de las lenguas romances y árabe facilitaba dicha tarea, habitual entre los judíos cortesanos del Conquistador.

Sin embargo, lo realmente significativo y trascendente fueron las donaciones de Jaime I, algunas de las cuales se consignaron en el Llibre del Repartiment. Corresponden al año 1248, pero el asentamiento es anterior, ya que en una de las concesiones se alude a las casas y tierras que poseían (quas tenent), o a la calle que fue asignada a los judíos. Los datos que poseemos son los siguientes:

- En 1248 se dan a Pere d'Odena unas casas en la calle que fue asignada a los judíos.

- Se dan a Benet Gil casas y tres jovadas de tierras contiguas a la honor de mestre Guido y de Aarón, judío.

- El 25 de septiembre de 1248 se dan a Bono Abinçalel, Jucef Abingalol, Abrahim Abinçalel, Aarón Abinlatram y Musa Abinçalel cuatro casas, que ya tenían, y una jovada y media de viña.

- El 6 de marzo de 1249 se entregan a Salamó, alfaquí, unas casas francas ${ }^{15}$.

Baer da la noticia de que «el barrio judío de Játiva fue restaurado tras la conquista de la ciudad", pero sin especificar en que basa tal afirmación. Ello presupone la existencia de una judería en la etapa anterior y una continuidad en el marco físico, que por el momento no podemos probar. Lo único cierto es que los judíos fueron instalados en fecha posterior a la conquista y antes o en 1248, pero que no podemos precisar por el momento al no conocer el documento, en una calle propia (carraria qui fuit assignata judeis). Por tanto, en estos primeros años de la repoblación no existe un barrio judío, sino tan sólo una calle, lo que implica una comunidad poco numerosa. Tampoco son muchas las donaciones hechas

15 Llibre del Repartiment de Valencia, Ed. dirigida por A. Ferrando Francés. Valencia, Vicent García, 1979, pág. 239, n. ${ }^{\circ} 2584$; pág. 249, n. ${ }^{\circ} 249$; pág. 262, n. ${ }^{\circ} 2805$; pág. 264, n. ${ }^{\circ} 2822$ 
a hebreos en Xàtiva en estos primeros años, o al menos las conservadas en el Repartiment, y en su mayoría son miembros de la familia Abinçalel.

En estos años debió producirse un lento goteo de judíos que se van instalando en la ciudad, atraídos por las franquicias otorgadas por Jaime I. El 2 de julio de 1258 el monarca prorroga por dos años más el privilegio de exención de pecha, tributo, servicio, etc., concedido ya antes por un plazo de cinco años a Mossé Abengayet, de Xàtiva ${ }^{16}$. Es interesante constatar la intensa arabización que presentan los antropónimos de estos judíos asentados en Xàtiva en los años posteriores a la conquista: Abinçalel, Abinilatram, Abengayet, Abenzunana, etc., lo que permite suponer su anterior vinculación con el mundo musulmán valenciano, con la etapa anterior a la conquista, e incluso, quizá, residiendo en la misma Xàtiva. En cualquier caso no sabemos de donde procedían estos judíos.

En los años sesenta de la centuria comienza a ser más abundante la documentación sobre los judíos setabenses, como la reclamación hecha en 1263 por los hijos de mestre Aarón, alfaquí del rey (médico o especialista en cultura árabe, según interpretaciones de Romano o Burns), Isaac y Samuel, de una heredad que fue de su padre y que al morir éste dio a Joan de Garriga, problemática que estudió Burns ${ }^{17}$. El historiador norteamericano ha puesto de manifiesto la política de atracción de repobladores judíos en el reino de Valencia, incluyendo la ciudad de Xàtiva, mediante la concesión de numerosas franquicias, en particular las fiscales. Ya vimos la confirmada en 1253 a Mossé Abengayet.

Estas exenciones fiscales planteaban problemas a la aljama cuando ésta tenía que hacer frente a sus responsabilidades tributarias o comunales, y en 1261 Jaime I aclaraba a los judíos de Xàtiva que ninguno de ellos, a pesar de las franquicias obtenidas, estaba exento de sus obligaciones vecinales, debiendo cumplir con sus obligaciones tributarias una vez finalizado el período de gracia fiscal concedido. En 1260 el impago de los impuestos era ya un problema grave para la aljama, que pedía al monarca que se aclarase la situación, posiblemente porque muchos de los judíos que se habían instalado, pasado el plazo de franquicia, no contribuian en las cargas impositivas. El rey insiste en que los que tienen sus escrituras vencidas paguen.

\footnotetext{
16 Regne, J., History of the Jews in Aragon. Regesta and documents, 1213-1327, Hispania Judaica, n. ${ }^{\circ}$ 106. Jerusalén 1978, pág. 20.

17 Bunns, R. l. Moros, cristians i jueus, págs. 231-232, en el apartado «Els fills de l'alfaquim» analiza con detalle el mencionado documento.
} 
El poblamiento judío -al igual que el cristiano- era lento y en 1268 , para atraer nuevos pobladores, Jaime expide un privilegio por el que los judíos que vengan a Xàtiva quedarán exentos durante cinco años del pago de tributos, exacciones y obligaciones reales desde el día de su llegada. En 1273, transcurridos los cinco años, el monarca tuvo que intervenir personalmente en defensa de Isaac ben Yanah, judío de Toledo, para que se le aplicara dicha franquicia, a lo que se negaba la aljama. En 1274 otro privilegio de Jaime I establecía que cualquier judío que acudiera a poblar Xàtiva tendría la franquicia pasados los cinco años que se concedió de exención a los judíos que se instalaron allí. Si en el plazo de ocho años cambiaba su domicilio a otro lugar, debería abonar antes de hacerlo todas las pechas, tributos y cargas reales percibidas por la aljama durante el tiempo que residió en la ciudad ${ }^{18}$. Era una medida apropiada para conseguir fijar la población judía en Xàtiva, que era el centro de una comarca con una densa población mudéjar, en unos años particularmente inciertos, de revueltas e inseguridad. En cualquier caso para entonces los judíos ya estaban consolidados en Xàtiva y los documentos hablan de la judería y de la aljama. Estaríamos ante una judería de tipo medio, a la que Baer calculó - no sabemos en base a qué criterio - una población, de unas cincuenta familias ${ }^{19}$. Lo cierto es que no hay ningún demográfico para la mencionada aljama.

La instalación de los judíos en Xàtiva planteó desde el primer momento problemas de convivencia con los cristianos, al igual que en otras muchas localidades, como consecuencia de su posición de inferioridad dentro del orden social y político, que se plasmó en una serie de medidas segregacionistas, comenzando por su ubicación espacial en calles o barrios especiales para terminar forzándoles a escuchar las predicaciones de frailes o limitando sus contactos con los cristianos. La religión era el arma ideológica, la gran excusa para oprimir y vejar al judío de cualquier forma. El problema se agravaba en el periodo de Cuaresma, cuando la celebración de la Semana Santa y la Pasión de Cristo despertaba todos los odios y recelos de los cristianos, que veían en el judío al pueblo deicida. Mientras la Iglesia arreciaba en sus disposiciones contra los judíos, Jaime I adoptaba medidas contra los fanáticos cristianos, protegiendo a las aljamas y judíos de cualquier violencia. Los judíos eran una buena fuente de ingresos, formaban parte del patrimonio real y el monarca los consi-

16 Burns, R. I., Cristians, moros i jueus, págs. 239-244.

19 BAER, Y., Historia de los judíos, pág. 158. La noticia la transmite R. I. Burns en su obra "Jaume I i els jueus", en Jaume / i els valencians del segle XIII., Valencia, Tres i Quatre, 1981, pág. 156. 
deraba como "nostre tresor», un bien que había que proteger. Es lo que sucedió en Xàtiva el 25 de abril de 1268, fecha en que el rey dio orden al alcaide y al «Consell» de la ciudad de proteger a los judíos, sus casas y bienes, en particular el día de Viernes Santo, así como cerrar la torre lindante con el cementerio judío, cerca de la escalera adosada al muro, con el fin de impedir que se arrojen piedras sobre las casas judías. En la puerta de "Algesna" todos los años el día de Viernes Santo, tras la celebración de la misa, se pondría un hombre armado vigilando dicha puerta para impedir que ningún niño u otro penetre en la "Algesna» (?) para causar daños en las casas judías ${ }^{20}$.

A partir de los años sesenta la judería de Xàtiva aparece ya plenamente constituida como aljama y como tal la vemos negociando diversas peticiones al monarca o siendo destinataria de las diversas disposiciones reales. $Y$ dictando sus propias normas internas, de orden económico, religioso, de asistencia o enseñanza, o como hizo la aljama setabense prohibiendo llevar vestidos de joyas y colores, que podían escandalizar a la comunidad. El 10 de febrero de 1283 el infante Alfonso fue informado por Samuel, alfaquí del rey, que a pesar del privilegio que les había concedido Pedro el Grande a él y sus parientes para llevar el vestido que quisieran, la aljama de Xàtiva, a tenor de una tacanot interna, impedía a David Allevi, Abrahim Abenvives y Jucef Avengalell, primos de Samuel, llevar vestidos de color y otros ornamentos. El infante instará a la aljama a que les permita llevar los vestidos que quieran, a pesar de las disposiciones internas de la aljama ${ }^{21}$. Una vez más vemos a la minoría de judíos con influencia, dinero o cargos cortesanos beneficiarse del apoyo real para escapar a las medidas que discriminaban al resto de sus correligionarios, una de las cuales era el vestido.

Los judíos dependían directamente de la Corona, con la que mantuvieron estrechos lazos, fundamentalmente de tipo económico, y es bien conocida la interpretación que de ello dan los monarcas, que consideran a sus vasallos judíos como «nostre tresor». El hebreo aparece, sobre todo, como una fuente regular de ingresos, bien a través de las peytes o pechas,

20 Archivo de la Corona de Aragón (A.C.A.), Cancilleria real, reg. 15, vol. 95 v. La noticia la reproduce escuetamente BAER en su Histo ria de los judíos, págs. 128-129. La regesta la he tomado de REGNE, History of the Jews, n. ${ }^{\circ} 377$, pág. 67. El no haber podido aún consultar el documento original me impide saber si la lectura que da de la puerta como «Algesna»-..nombre que no identifico - es correcta o no. En cualquier caso es el mejor dato para poder ubicar con precisión la judería de Xàtiva.

21 A.C.A., Cancillería real, reg. 60, fol. 25 r. Regne, J., History of the Jews, n. 1021, pág. 183. BaER, Y., Historia de los judíos, pág. 188. Da el año 1283 como fecha de la citada ordenanza. Burns, R. I., Jaume / $i$ els jueus, pág. 180. 
bien con motivo de los frecuentes subsidios extraordinarios de que son víctimas. Los judíos de Xàtiva entregaban en 1271 una contribución anual de mil sueldos, que años más tarde - 1274 - se rebajó a la cifra de 600 sueldos, sin duda con ánimo de atraer pobladores.

Las contribuciones extraordinarias fueron frecuentes y por las más diversas motivaciones. La más antigua que hemos encontrado para Xàtiva es en el subsidio de 52.100 sueldos otorgado en 1271 por las aljamas de la Corona de Aragón a Jaime l. Los judíos valencianos contribuyeron sólo con 2.100 sueldos - lo que puede ser interpretado como síntoma de la debilidad económica de nuestras aljamas, en fase aún de formación y consolidación - y se hace mención específica de las aljamas de Valencia, Xàtiva, Alzira, Sagunto y Gandía. Estas cargas impositivas extraordinarias no eran aceptadas de buen grado por las aljamas, planteándose problemas a la hora de los repartos y de la contribución de cada una o la forma de tasar a sus integrantes. Por ello eran frecuentes las convocatorias enviadas por el rey a las aljamas para que éstas envíen sus representantes a su corte, con el fin de discutir estos u otros problemas económicos. Se conservan algunas de estas citaciones, como la del 1 de septiembre de 1271 , en la que la aljama setabense debía enviar dos delegados, igual que la de Sagunto, frente a los cuatro de Valencia. Es un dato que nos sirve también como elemento comparativo de la importancia de las mencionadas aljamas. O la hecha el 25 de febrero de 1274 por Jaime I para que cada aljama envíe dos delegados a Barcelona el domingo anterior a la fiesta de Ramos ${ }^{22}$.

Durante el reinado de Pedro III el Grande los judíos hubieron de satisfacer numerosas derramas con el fin de contribuir a los gastos derivados de la política internacional del monarca, a raíz de su intervención en Sicilia. Ya antes de estos sucesos, en 1280, hubo un subsidio por los judíos valencianos, y entre las aljamas contribuyentes aparece la de Xàtiva. En 1285 se pidió a los judíos valencianos un subsidio de 30.000 sueldos con destino a la armada real. Tan elevada cantidad no fue bien aceptada por los judíos y el 22 de octubre Pedro el Ceremonioso ordenaba a su procurador en el reino de Valencia que obligara a los judíos de Xàtiva a contribuir con la aljama de Valencia en el pago de lo que les queda por satisfacer de la mencionada suma, acordada con el rey, lo que indica que eran cantidades pactadas, en las que el tira y afloja por ambas partes estaba a la orden del día ${ }^{23}$.

22 A.C.A., Cancilleria real, reg. 18, fol. 105 r. Regne, J., History of the Jews, n. ${ }^{\circ}$ 99, pág. 99.

${ }^{23}$ A.C.A., Cancilleria real, reg. 57, fol. 222 v. REGNE, J., History of the Jews, $n .{ }^{\circ} 1458$. 
Debemos recordar que en aquellos momentos había una fuerte tensión en el seno de las aljamas, derivada de la forma de repartir entre sus miembros los impuestos, tanto los reales como los ordinarios de la propia comunidad, ya que determinados miembros, la oligarquía que controla el poder político y económico, intentaba mediante concesiones reales esquivar el pago de estas cargas, que recaían sobre las clases inferiores. Igual que sucedía en la sociedad cristiana. Las tendencias "democratizantes" abogaban por un reparto más equitativo del impuesto. El 24 de mayo de 1285 Pedro III recuerda a las aljamas de Valencia, Sagunto y Xàtiva, y a las demás del reino, que ha ordenado repartir por sueldo y libra los gastos en los asuntos para los que había convocado a sus secretarios y procuradores. Pero en Xàtiva parece que algunos judíos no querían abonar dichos gastos por ese sistema, con el pretexto de que cada aljama debe entregarlos a sus procuradores. El rey ordena a estas aljamas hacer el reparto de los gastos de forma similar al que se efectúa para otras tachas o exacciones ${ }^{24}$. Otra contribución extraordinaria de 6.000 sueldos fue reclamada por Alfonso III a los judíos del reino, pero sus dificultades económicas hicieron que el rey se la rebajara a 4.000 , de los cuales 3.000 los abonaría la aljama de Valencia, 600 la de Sagunto y 400 la de Xàtiva ${ }^{25}$. Todo parece apuntar a que ya en estas fechas la aljama setabense era la tercera del reino, nivel que mantuvo hasta el final de su trayectoria histórica.

Durante el reinado de Pedro III el hecho más trascendente es la presencia de funcionarios judíos desempeñando cargos de gobierno, tema que ha sido bien estudiado por D. Romano ${ }^{26}$, para quien «constituyeron una categoría social típica del siglo xIII que nunca más volvió a existir». Su momento de esplendor lo alcanzan en la primera parte del reinado de Pedro III hasta que el Privilegio General de 1283 y otras disposiciones legales marginaron a los judíos del ejercicio del poder político. Entre los funcionarios judíos que encontramos en Xàtiva aparece Mossé Almateri, documentado en 1280 como baile de la localidad, documentado en diversos actos desde el 13 de febrero de 1280. Entre ellos vemos la orden dada por el rey al justicia de Xàtiva para que rinda cuentas del justiciazgo a Almateri y que no le moleste en el desempeño de su cargo ${ }^{27}$, noticia

\footnotetext{
${ }^{24}$ A.C.A., Cancilleria real, reg. 56, fol. 107 r. Regne, J., History of the Jews, n. ${ }^{\circ}$ 1360, pág.

25 A.C.A., Cancilleria real, reg. 78, fol. 71. REGne, J., History of the Jews, n. ${ }^{\circ} 1794$.

26 Romano, D., Los funcionarios judios de Pedro el Grande de Aragón. Barcelona 1970.

${ }^{27}$ Romano, D., Los funcionarios judios, págs. 138-139, recoge todas las noticias que hacen referencia a Mossé Almateri, por lo que considero innecesaria su repetición.
} 246. 
interesante por cuanto revela el tradicional enfrentamiento entre las dos jurisdicciones, la local y la real, y el recelo que para el justicia cristiano suponía un baile de religión judía, al que procuraría vejar y discriminar tan pronto como se le presentara la ocasión.

En 1281 fue baile de Xàtiva y otros lugares Judá Manasseh, hijo de Abraham ben Nahmias, y también desempeñó el cargo de canciller de árabe el tiempo en que su hermano Samuel ben Manasseh permaneció junto con Pedro III en Sicilia. En enero de 1282 fue encargado de recaudar el impuesto sobre los fuegos de los moros del reino ${ }^{28}$. También por entonces actuaba en Xàtiva el judío Samuel, alfaquí del rey y secretario mayor de escritura arábiga. Ya vimos como en 1283 el rey concedió licencia a unos parientes suyos a que llevaran cierto tipo de vestidos, cuyo uso había prohibido la aljama setabense.

Xàtiva era por entonces un enclave cristiano en medio de un territorio densamente poblado de mudéjares. Los judíos eran una exigua minoría, pero obligados a relacionarse con sus vecinos moros. Ya los hemos visto como bailes o como recaudadores de tributos sobre moros. Pero éstos no estaban dispuestos a tolerar la injerencia judía en asuntos de su comunidad. En la carta puebla de la morería setabense había un apartado en el que se especificaba que ningún judío pudiera ser baile de moros ni colector de sus rentas. Como se ve, la corona no dudaba en saltarse estas normas cuando le interesaba.

Mucho más estrictas eran las normativas legales referentes a los contactos sexuales entre miembros de las tres religiones, absolutamente prohibidas y castigadas con fuertes penas, para evitar cualquier posible forma de contagio religioso. Lo que no excluye que las hubiera, como se deduce de la orden dada el 23 de abril de 1283 por el infante Alfonso a Ximén Pérez de Zapata, lugarteniente del procurador dellà Xúquer, para que haga observar a los moros la orden dada por Rodrigo Jiménez de Luna, procurador real, sobre las relaciones adúlteras entre cristianos y judíos, de un lado, y los moros de Xàtiva, del otro ${ }^{29}$. La religión era otro asunto en el cual las autoridades no admitían transgresiones a las normas establecidas y el 6 de julio de 1284 Pedro el Grande ordenó condenar a muerte a una judía, Maulet, que se había convertido al islam ${ }^{30}$. Parece que en tiempos de Jaime I se había dado otro caso similar.

28 Burns, R. 1., Colonialisme medieval, pág. 365.

29 A.C.A., Cancilleria real, reg. 61, fol. 101 v. REGNE, J., History of the Jews, n. ${ }^{1045}$, pág. 187.

so A.C.A., Cancilleria real, reg. 46, fol. 221 v. REGNE, J., History of the Jews, pág. 221 v. 
Continuando con una vieja tradición histórica, Xàtiva siguió siendo tras la conquista cristiana un importante centro cultural, además de administrativo. Xàtiva se convierte, como señala Burns, en el centro de la Valencia mudéjar ${ }^{31}$. La Iglesia monopolizaba dicha cultura, que en el caso que nos interesa son las escuelas filosóficas de árabe, encargadas de formar especialistas de la controversia con estudiosos musulmanes. De ellas, la más constante, estuvo en Xàtiva, bajo la dirección de los dominicos, que aunque habían recibido tierra para asentarse en la ciudad en 1248, posiblemente no lo hicieron hasta 1291.

No se han conservado documentos de la escuela de árabe de Xàtiva hasta 1291. Los prioratos dominicos de Valencia y Xàtiva disputaron por sus respectivas jurisdicciones para predicar por el nuevo reino, quedando para Xàtiva los territorios desde el Júcar a Bañeres. En 1291 Jaime II, a instancias del prior del convento de predicadores de Xàtiva, enfranquece a Yom Tob, judío de la villa, así como a sus bienes muebles e inmuebles, de toda pecha, questia, servicio, subsidio, hueste y cabalgada, así como otros impuestos reales durante el tiempo que ejerciera como maestro de hebreo en el citado convento ${ }^{32}$. En 1303 el prior setabense recibió órdenes de contratar un judío, entendido en árabe, o algún moro que pudiera enseñar junto con fray Pere Escarramat. El 13 de agosto de 1308 Blanca de Anjou, esposa de Jaime II, en su testamento dejaba un fondo de ayuda a los dominicos de Xàtiva para que estudien árabe y hebreo, mienitras dure el citado estudio, pero si llegaba el caso, que el dinero fuera a las monjas de Santa Matía Magdalena de Valencia, lo que refleja el cambio y desplazamiento de las escuelas de lenguas ${ }^{33}$. No sabemos en qué fecha desapareció la escuela arábica de Xàtiva, aún cuando puede suponerse que debió ser en estas primeras décadas del siglo XIV.

De las actividades ejercidas por los judíos setabenses en esta primera etapa hay pocos datos. Cabe pensar en una mayoría de hebreos dedicados a labores artesarias, en particular la del textil: sastres, ropavejeros, tejedores, etc., cuero, orfebrería, aunque no hay menciones concretas de los mismos. No faltó, claro está, la práctica del préstamo con interés, derivado en usura, y el 23 de junio de 1280 Pedro III concedía un perdón a la aljama de Xàtiva (igual que a los restantes judíos de Cataluña y Valencia) de posibles delitos de usura ${ }^{34}$.

\footnotetext{
31 Bunns, R. I., Moros, cristians i juens, pág. 150. En el apartado «Escoles filosòfiques d'àrabic" analiza con detalle la evolución de la de Xàtiva.

${ }^{32}$ A.C.A., Cancilleria real, reg. 195, fol. 94 r. REGNE, J., History of the Jews, n. 2969.

33 Burns, R. I., Moros, cristians i jueus, pág. 151.

${ }^{34}$ REGNE, J., History of the Jews, n. ${ }^{\circ} 791$, pág. 143.
} 
También practicaron el comercio al detalle y contaban con sus propias tiendas, pues una orden de Jaime II en 1298 concedía a la aljama de esta ciudad que por impago de pechas $u$ otras deudas ningún funcionario real podía embargar los comercios de los judíos, sino sólo sus casas, como sucedía en Valencia ${ }^{35}$. Sabemos que en Xàtiva, igual que en Valencia, existía un açoch judío, integrado por tiendas y obradores de artesanos.

Queda por resolver el problema del emplazamiento de la judería de Xàtiva. El único que se ha preocupado del tema ha sido A. Ventura, para quien la «jueria estiqué entre la muralla de la ciutat, que la separava de la moreria (carrer del Mur, plaça de la Galera o de Sant Jordi i Carrer de les Animes) i l'església principal (la Seu, i Sant Domènec)». «El límit est de la jueria seria el Carrer Menor, que talla de dalt a baix entre el Carrer de Sant Agustí (mes estret) i el de Sant Domènec (més ample): precisament en aquesta intersecció podria haver-hi una porta del call. El carrer central del barri seria el de les Santes, que uniría les dues posibles sinagogues, la vella, que seria la ermita de les Santes, i la nova, que seria Sant Agustí» ${ }^{36}$. Al margen de algunas inexactitudes de nomenclatura, como el término call, que nunca se utiliza en el reino de Valencia - aquí es el de juería- y sí en Cataluña, no hay ningún testimonio que permita suponer que éste fue con precisión el límite de la judería. Mucho menos que se mantuviera inmutable entre 1245 y $1492 \mathrm{ni}$, por supuesto, que hubiera dos sinagogas, ya que salvo Valencia no se conoce ninguna aljama valenciana que las tuviera. La única noticia de la sinagoga de Xàtiva es su reedificación en 1321, con unas medidas de 55 palmos de alto, y 7,5 brazas y 2,5 palmos de ancho ${ }^{37}$.

Sí parece pausible suponer que los judíos estuvieron localizados entre el castillo y la iglesia parroquial, la actual Seu, como era habitual en muchas otras localidades, buscando protección y seguridad. Sabemos, por otra parte, que en un principio los judíos setabenses residían en una sola calle, dado su escaso número, que les fue asignada por Jaime I (carraria qui fuit assignata judeis), como ya vimos, pero sin que se especifique su emplazamiento. Ventura alude a un documento de 1252, publicado por Miret i Sans, referente a «una alhóndiga (que) estaba junto a la iglesia de Santa Tecla, frente al almudín del tiempo de los sarracenos

35 A.C.A., Cancillería real, reg. 196, fol. 172 r. REgne, J., History of the Jews, $n{ }^{\circ} 2695$. Hinojosa Montalvo, J., "Los judíos valencianos durante la época de las Vísperas Sicialianas (1276-1336)", XI Congreso di Storia della Corona d'Aragona. Palermo 1984, pág. 207.

36 Ventura, A., Possible localització, págs. 31-32.

37 A.C.A., Cancilleria real, reg. 219, fol. 198 v. Regne, J., History of the Jews, n. 3174. Hinojosa Montalvo, J., Los judios valencianos, pág. 211. 
y los talleres (operatoria) de los judíos». Parece, pues, que por esta razón se fueron extendiendo los judíos a partir de una primera calle y el 10 de marzo de 1307 Jaime II concedió a la aljama de Xàtiva y sus miembros habitantes en el açoch y en el perímetro del almudín (circuitu almudinii) un privilegio por el que nunca podrían ser trasladados a otro lugar ${ }^{38}$. Sabemos también que había casas judías y el cementerio de la comunidad que estaban adosados a la muralla, junto al muro de la "Algesna", donde colocaba protección armada el Viernes Santo para evitar apedreos de los judíos y sus viviendas. El cementario fue rodeado de una cerca protectora en 1321, aprovechando quizá un buen momento económico de la aljama, que permitió también reedificar la sinagoga, como hemos vistos. La carnicería la tuvieron en el arrabal de les Barreres.

\section{LAS DIFICULTADES DEL SIGLO XIX}

La evolución del judaísmo valenciano sigue una evolución paralela a la de la sociedad dominante cristiana, junto a la cual se sitúa, aún cuando cada judería tiene su propio ritmo histórico. Por tanto, los años centrales del siglo XIV, casi hasta las vísperas de los alborotos de 1391 va a ser una etapa difícil para la judería de Xàtiva, como también para las restantes del reino, aunque es un tema aún poco y mal conocido. De hecho en la obra de Baer, por ejemplo, no hay ninguna referencia a la judería de Xàtiva en el siglo XIV hasta 1391.

Entre 1346 y 1375 se extienden los tiempos difíciles. De todos es sabido que esta centuria ha merecido ser llamada "el siglo de las crisis", que afectó a los más diversos aspectos de la vida del hombre de la época, desde la demografía a la creencias religiosas. No sabemos cuándo se produjo la ruptura en la supuesta línea de crecimiento de la aljama de Xàtiva. Por ejemplo, si la afectó la crisis de subsistencias que se produjo en muchos lugares del reino, aunque el final de la década de los treinta debió de ser un momento de apuro económico, como lo refleja las continuas rebajas en las peticiones de subsidios hechas por el monarca. Tampoco conocemos las posibles repercusiones negativas que el conflicto de la Unión tuvo en la aljama. Lo que sí que podemos afirmar es que la epidemia de peste negra desatada en 1348 ocasionó una sangría demográfica, en una proporción en que no podemos evaluar, pero que debió ser alta, teniendo en cuenta las condiciones de hacinamiento en que solían

38 A.C.A., Cancillería real, reg. 205, 10-3-1307. Valencia. 
vivir las colectividades hebreas en muchas localidades. La epidemia aparece ya en mayo de 1348 en Valencia. El 5 de junio Pedro el Ceremonioso para hacer frente a la pobreza de la aljama autoriza a los judíos a que en los próximos seis años puedan imponer a los miembros de la aljama y de su contribución sisas en todas las mercancías que compren y vendan, pudiendo aumentarlas o disminuirlas según su voluntad ${ }^{39}$. Es posible que para esas fechas la peste hubiera hecho su aparición y hubiera dejado su rastro de mortandad en Xàtiva y los judíos hubieran solicitado medidas de ayuda al monarca, a la sazón en Valencia. Los 50 kilómetros que separan Xàtiva de Valencia permiten una rápida difusión de las noticias y que Pedro IV disponga las medidas adecuadas para la recuperación económica y humana de la aljama.

Para paliar tan grave crisis la monarquía dio otras disposiciones subsidiarias, como la del 1 de julio de 1353 por la que se comprometía a no realizar inquisiciones contra los judíos en el plazo de cinco años, a partir de esa fecha. Ese mismo día autoriza a la aljama a que durante cuatro años pueda recaudar imposiciones sobre aquellas cosas que tradicionalmente se recaudaban en tiempo pasado ${ }^{40}$. Se buscaba recuperar el pulso económico de la aljama por la vía fiscal, totalmente desorganizada por la crisis demográfica. No olvidemos que las epidemias reaparecieron en años posteriores, lo que hizo aún más difícil la restauración.

A este negro panorama se añadió un suceso político de incalculables consecuencias: la guerra entre Castilla y Aragón, conocida como de los dos Pedros, que tuvo en el reino de Valencia uno de sus principales escenarios entre 1356 y 1366 , prolongándose el clima de inseguridad hasta 1375. Muertes, cautiverios, emigraciones, pérdida de bienes, etc., fueron generales por todo el reino, afectando por igual a moros, cristianos y judíos, aunque sin que, por ahora, podamos precisar con muchos datos concretos.

Si los judíos no intervinieron directamente en las acciones militares del conflicto, sí lo hicieron desde el punto de vista financiero, mediante continuas aportaciones monetarias. El apoyo de Pedro IV a las comunidades hebreas no era desinteresado, sino que a cambio exigía su apoyo económico. Ello hizo que la presión fiscal durante el reinado del Ceremonioso sobre las comunidades judías tuviera un efecto tan desastroso o más que la propia guerra, hasta el punto de llevar a muchas de ellas al empobrecimiento. Recordemos que la Hacienda de Pedro IV estaba exhausta y era

39 A.C.A., Cancillería real, reg. 887 , fols. $17 \mathrm{v}-18 \mathrm{r}$.

40 A.C.A., Cancillería real, reg. 896 , fols. 43 r-v y 55 r. 
incapaz de hacer frente a las necesidades de dinero del rey. La solución era exprimir a sus súbditos, sin importar la religión, aunque éstos aprovecharon la ocasión de la guerra - que consideraban una guerra del reypara obtener también importantes ventajas de orden político o económico.

Son muy numerosas las peticiones de numerario hechas por Pedro IV desde su ascenso al trono en 1336. Ya el 26 de marzo de 1336 solicitaba a diversas aljamas del reino un subsidio para sus coronaciones y para el ejército, correspondiendo abonar a la aljama de Xàtiva la suma de 2.000 sueldos, pagaderos la mitad en julio y la otra mitad en octubre a García Morell, portero real ${ }^{41}$. A título comparativo digamos que Sagunto pagó 6.000 sueldos y Castellón otros 1.000 , lo que sitúa a la aljama setabense en una posición intermedia entre las valencianas.

Una nueva petición tuvo lugar en 1337, siendo la contribución de Xàtiva de 8.000 sueldos (Sagunto, 20.000), pero lo elevado de la suma pedida y las quejas de las aljamas obligó a una reducción, que para Xàtiva quedó en 3.500 sueldos, a entregar en los meses de mayo y septiembre de ese año ${ }^{42}$. En 1338 a la aljama de Xàtiva se le pidió un subsidio extraordinario de 4.000 sueldos, aunque luego Pedro IV en carta desde Barcelona el 26 de mayo les perdonó $3.600^{43}$. La contribución extraordinaria de 1339 fue de 2.800 sueldos.

La guerra con Castilla fue el justificante que permitió a la Corona exigir continuas derramas monetarias a sus vasallos judíos, que en ocasiones las puso en difícil situación financiera, pues la coyuntura socio-económica de estos años no era la más propicia para hacer frente a tan repetidas exacciones. A modo de muestreo digamos que en el subsidio solicitado por el Ceremonioso el 1 de marzo de 1356 a sus aljamas para la defensa del reino de Cerdeña y otras empresas, Xàtiva abonó 1.500 sueldos $^{44}$. El 1 de febrero de 1357 el monarca pidió como ayuda para la guerra de Castilla 2.000 sueldos a la aljama setabense ${ }^{45}$. El subsidio de 1362 fue

41 A.C.A., Cancilleria real, reg. 1501, fols. 23 r-24 r.

42 A.C.A., Cancillería real, reg. 1501, fols. 41 r-v. La aljama de Valencia no pagó nada en ese subsidio por exención expresa del rey, en virtud de los gastos que la aljama había tenido y del dinero que entregaron a Vidal de Viianova.

${ }^{43}$ A.C.A., Cancillería real, reg. 1501 , foi. 96 v. A título comparativo digamos que la aljama de Castellón fue tachada en 600 sueldos, Alzira en 400, Sagunto en 6.000, Girona en 30.000 y Lérida en 2.000 .

${ }^{44}$ A.C.A., Cancillería real, reg. 1403, fol. 1 r-v. Valencia contribuyó con 10.000 sueldos, Alzira 1.000 sueldos, Burriana 1.500 sueldos, Villarreal 200 sueldos, Sagunto con 500 sueldos. La exigua suma de esta última aljama se explicaría por su estado de postración como consecuencia del asalto de las tropas unionistas valencianas.

${ }_{45}$ A.C.A., Cancillería real, reg. 1380 , fol. $178 \mathrm{r}-\mathrm{v}$. Valencia entregó 15.000 sueldos, Sagunto 500 y Alzira 1.500. 
de 2.800 sueldos y el de 1365 de 2.500 , pagaderos la mitad en mayo y el resto en septiembre al baile local, Bernat Roca ${ }^{46}$.

Las aljamas trataron por todos los medios de rebajar las cantidades pedidas por la Corona, para lo cual se llevaban a cabo negociaciones entre las partes. El 1 de febrero de 1369 la reina Leonor escribe a los bailes de Xàtiva, Lliria, Alzira, Burriana y Sagunto porque se ha enterado que el tesorero del rey ha enviado a estas aljamas una carta de Pedro IV ordenándoles que nombren unos síndicos con poderes para tratar con el tesorero la cantidad que razonablemente cada aljama pudiera pagar como ayuda a los gastos de defensas de sus Estados frente a la invasión armada que tiene lugar por Cataluña. La reina ordena que se sobresea dicha medida, ya que no quiere cargar con gastos a las aljamas, y prohíbe que en el futuro el tesorero haga más peticiones, aunque no está convencida de que así se haga. Por ello da por cancelado el nombramiento de dichos síndicos y cualquier pago pedido a las aljamas hasta que reciban una orden especial de la reina ${ }^{47}$.

El resultado final de tanta opresión y dificultades fue la pobreza y práctica ruina de la aljama en los años setenta, aunque tal situación arrancaba de las décadas anteriores. Para poner remedio a tal situación, que de ningún modo interesaba a la Corona, pues perdía unos buenos ingresos, la monarquía adoptó diversas medidas de gracia. Por ejemplo, el 20 de marzo de 1366 la reina Leonor concedió a la aljama de Xàtiva que durante los próximos cinco años los oficiales reales no hicieran inquisición contra los judíos, disposición que fue ratificada por su hijo, el infante Juan el 4 de febrero de $1371^{48}$. El 17 de febrero Pedro el Ceremonioso, deseando restaurar la aljama setabense de los daños que ha sufrido, autoriza a los judíos a que puedan recoger y albergar en sus casas a cualquier persona, sin que importe su grado, ley o condición social ${ }^{49}$. Por otro privilegio del 18 de febrero de ese año el rey se compromete a que en el plazo de cinco años ni él ni sus oficiales harán inquisiciones a los judíos y la aljama sobre las usuras ni sobre los contratos entre los judíos $y$ sus acreedores ${ }^{50}$.

Este estado de pobreza hizo que muchos judíos setabenses abandonaran sus casas de la judería y trasladaran su domicilio a otros lugares,

\footnotetext{
A.C.A., Cancilleria real, reg. 1583 , fol. $66 \mathrm{r}$.

A.C.A., Cancilleria real, reg. 1577 , fols. 33 v-34 v.

A.C.A., Cancilleria real, reg. 1678 , fols. 128 v-129 v.

A.C.A., Cancillería real, reg. 920 , fol. 79 v.

A.C.A., Cancilleria real, reg. 920 , fol. $80 \mathrm{r}$-v.
} 
lo que redundaba en una disminución de los derechos de la reina, razón por la cual doña Leonor ordenó al baile de Xàtiva que prohibiera a los judíos cambiar de residencia, bajo las penas pecuniarias que considerara oportunas ${ }^{51}$. La documentación nos refiere que la aljama de Xàtiva estaba al borde de su desaparición en 1373, por lo que la reina Leonor, a cuya cámara estaba asignada, el 20 de febrero de 1373, le perdonó ese año la pecha ordinaria de 2.800 sueldos anuales ${ }^{52}$. Esta gracia se repitió en 1374, aunque no fue óbice para que la reina pidiera a los judíos de Xàtiva en 1373 una contribución extraordinaria de 2.500 sueldos $^{53}$.

La restauración de la aljama se produjo en la década de los ochenta, una vez que finalizó la etapa bélica y la vida económica recobró su pulso en el territorio. La Corona impulsó esta recuperación con diversas gracias, como la aprobación el 28 de junio de 1382 por el infante Juan de todos los privilegios que él, su padre el rey y sus antecesores habían concedido a la aljama de Xàtiva. Ese mismo día, a petición de la aljama, perdonó a la comunidad y particulares de cualquier petición, demanda, así como penas civiles o criminales, 0 de otro cualquier delito cometido hasta la fecha, a excepción de los sodomitas, malsines, falsificadores de moneda, así como los que yacieron con cristianos o los que practicaban hechicerías, excepciones que eran las habituales en este tipo de perdones generales. Los judíos que estuvieran en la cárcel serían puestos en libertad por los oficiales reales a petición de los adelantados ${ }^{54}$. Estas medidas, junto con otros perdones de deudas y privilegios reales permitieron que la aljama de Xàtiva iniciara una etapa de recuperación, que se vio truncada por los alborotos de 1391.

\section{LOS SUCESOS DE 1391. DESAPARICIÓN DE LA ALJAMA}

Corría el 9 de julio de 1391. Ese día el furor antisemita, que partiendo de Sevilla se había ido extendiendo por la península, llegó a Valencia, donde las masas, excitadas por las noticias que llegaban del exterior y hábilmente manejadas, se lanzaron al asalto de la judería, que «fon robada, dissipada e svahida", hasta el punto de que no quedaron en pie más que las paredes de las casas ("sens dexar clau en paret", recogió con gran plasticidad el escribano del "Consell" de Valencia). El tema es

51 A.C.A., Cancilleria real, reg. 1581, fol. 59 v.

A.C.A., Cancilleria real, reg. 1751, fol. $108 \mathrm{r}-\mathrm{v}$.

A.C.A., Cancillería real, reg. 1581 , fols. $114 \mathrm{v}-115 \mathrm{r}$.

54 A.C.A., Cancillería real, reg. 1686, fols. $171 \mathrm{r}-173 \mathrm{r}$. 
bien conocido y no hace falta insistir en él, ya que no es el presente objetivo ${ }^{55}$, como tampoco en las consecuencias del mismo: muerte, huida o conversión de la mayoría de los judíos; descenso numérico de la población judía; desaparición de numerosas aljamas que ya nunca se recuperarían; reorganización del espacio y de la jerarquía de las aljamas hebreas en el reino de Valencia.

El asalto a la judería de Valencia no fue un suceso aislado, sino que se extendió por todo el reino, afectando a la mayoría de las aljamas, entre ellas la de Xàtiva. En una carta de los jurados de Valencia a sus embajadores en la corte real del 14 de julio se hacían eco de estas destrucciones: «e encara los de Xàtiva, d'Algezira e de Gandia... e los de Lliria e de Cullera», es decir las noticas de un radio de unos 60 kilómetros habían llegado rápidamente a la capital en unos días de gran tensión, en los que los acontecimientos se desarrollaban a un ritmo incapaz de ser controlado por las autoridades.

Se sabía, por tanto, que la judería de Xàtiva fue asaltada. Pero sin más precisiones. A. Ventura, el único que sintió curiosidad por el tema, se preguntaba si hubo una matanza de judíos el día del Salvador, el de la Transfiguración del Señor o el de San Sebastián, basándose en el nombre que tomaron las dos iglesias que él supone que eran sinagogas (nunca se ha demostrado que hubieran dos sinagogas en Xàtiva, hecho poco probable en una judería de pequeño o mediano tamaño), siendo la familia noble de los Bellvis los patrocinadores de esta transformación, quizá con conversos entre sus miembros.

Concluye diciendo que es posible que la judería quedara despoblada o la mayoría de los judíos convertidos a la fuerza ${ }^{56}$. Demasiadas posibilidades o hipótesis sin respuesta.

La documentación consultada permite disipar las dudas y recuperar el devenir histórico. Lo que está claro es que el asalto a la judería de Xàtiva

55 Danvila, F., «El robo de la judería de Valencia en 1391», Boletín de la Real Academia de la Historia, n. ${ }^{\circ}$ 8, 1886, págs. 370-371; VIDAL. BeLtrán, E., Valencia en la época de Juan I. Valencia 1974, págs. 54-59; Riera I SANS, J., "Los tumultos contra las juderías de la Corona de Aragón en 1391", Cuadernos de Historia, n. ${ }^{\circ} 8,1977$, págs. 213-225. Hinojosa Montalvo, J., The Jews of the Kingdom of Valencia. From Progroms to Expulsion (1391-1492). Jerusalén 1992.

${ }_{56}$ Ventura, A., Possible localització de la jueria, pág. 35. No hay ningún documento que indique que hubiera conversos setabenses integrados en el linaje de los Bellvis. En la nómina de procesados por la Inquisición en Valencia sólo aparecen tres apellidados Bellvis, ninguno de ellos de Xàtiva, en donde se contabilizan 58 judaizantes. Vid. García CárCel, R., Origenes de la Inquisición española. El tribunal de Valencia, 1478-1530. Barcelona, Península, 1976. Recordemos que fue habitual tras los saqueos de las juderías en 1391 que los nuevos convertidos al cristianismo tomaran el apellido de personas de relieve social o de aquellas con las que mantuvieron los judíos lazos de amistad o de negocios. 
no se produjo en las fechas arriba propuestas ( 20 de enero o 9 de agosto) ni hubo matanzas de hebreos.

El suceso presenta dos actos bien diferenciados el uno del otro: asalto y destrucción de la judería, por un lado, y actuación real para castigar a los culpables, por otro, al que se podría añadir un epílogo, que sería la transformación de la comunidad judía en conversa.

El desarrollo de los sucesos ha sido posible reconstruirlo gracias al relato que del mismo se hace en un documento real del 10 de enero de $1393^{57}$. Los hechos transcurrieron así: el lunes 10 de julio, al alba, llegó a la ciudad de Xàtiva la noticia de la destrucción y robo de la judería de Valencia, con su secuela de muertes, heridas de algunos de sus habitantes, siguiendo el ejemplo de lo que había sucedido no hacía mucho en Sevilla.

El rumor del suceso se extendió como la pólvora y algunas malas personas forasteras ("algunes desafrendades e males persones stranyes») - como siempre se trata de cargar las culpas en los de fuera y eximir a los propios- deseosas de robar y apoderarse de los bienes de los judíos utilizaron toda su oratoria a fondo para incitar a las masas y convencerlas de que la judería debía de ser destruida y los judíos convertidos al cristianismo. Queda claro, una vez más, el importante papel que juega la palabra, el discurso, como elemento de transmisión y aglutinamiento, así como el poder de captación de algunos de estos instigadores en los levantamientos populares, como el presente. Como resultado se desencadenó una fuerte tensión e inquietud por toda la ciudad.

Los oficiales reales -en Xàtiva residía el lugarteniente del gobernador "dellà Xúquer»-, los jurados y algunos particulares tuvieron que emplearse a fondo para poder contener la presión de los descontentos, para lo cual escribieron al hermano del rey y lugarteniente general, el duque de Montblanch, pidiéndole que dictara órdenes para calmar los rumores y ofreciéndose dichas autoridades a ayudarle en lo que fuera necesario. Al final del día, por tanto, parecía que la difícil situación podría ser controlada por los regidores urbanos. Pero, he aquí, que entonces llegó a Xàtiva otra noticia que daba cuenta de la conversión al mediodía del lunes de los judíos de la cercana Alzira, hecho que todavía exaltó más los ánimos de los instigadores antijudíos, y con $e$ ! respaldarazo moral que para sus propósitos suponía aquel hecho, el lunes 10 de julio al anochecer la judería de Xàtiva fue invadida, robada y dispersada («dilluns a vespre en la nit

57 A.C.A., Cancilleria real, reg. 1904 , fols. $148 \mathrm{r}-151 \mathrm{r}$. 
fon svahida, robada e disipada»). Por fortuna sólo murió un judío demente, que fue encontrado encadenado, ya que el resto de los hebreos, siguiendo los consejos y disposiciones de los jurados, imposibilitados de hacerse cargo de su defensa, se refugiaron en el castillo.

Al día siguiente, martes, se celebraba mercado en Xàtiva, al que acudía mucha gente de las comarcas vecinas e incluso de la zona fronteriza con Castilla. Entonces, a estos forasteros, junto con otros vecinos, no se les ocurrió otra idea para presionar a los judíos refugiados que cercarles por hambre, impidiendo la subida al castillo de cualquier tipo de alimentos, hasta que no tuvieran más remedio que abandonar la fortaleza, siendo bautizados cuando bajaran. Tremendo sistema para lograr la conversión, que no hemos encontrado en otros lugares. Y como lo planearon lo ejecutaron.

Las autoridades municipales, ante el tumulto desencadenado, utilizaron todos los recursos a su alcance, incluso con riesgo para sus personas, y dispusieron: $10^{\circ}$ la custodia de la morería de la ciudad, tanto de las personas como de los bienes, para evitar atropellos (igual que en Valencia se veía a los moros como el segundo posible objetivo de los sediciosos); $2 .^{\circ}$ insistir ante el duque de Montblanch para que de aquellos delitos diera un castigo ejemplar, ofreciéndose el «Consell» para cuanto necesitara; $3 .^{\circ}$ por orden de justicia se hicieron pregones por toda la ciudad, con el fin de que las personas que tuvieran moneda, vajilla, ropa u otros bienes de la judería que los manifestaran y devolvieran a las personas comisionadas por el «Consell» a tal fin. Las mismas medidas que en Valencia. La documentación refiere que tras dichos pregones se restituyeron grandes cantidades de bienes robados de toda índole.

Hasta aquí el escueto relato de los hechos. Juan I recibió pronto notificación de los hechos, ya que el 21 de julio, desde Zaragoza, y ante las noticias del ataque, rogaba a los jurados setabenses que defendieran a los moros de la ciudad de cualquier agresión ${ }^{58}$.

En cuanto a los participantes en el robo de la judería, el justicia criminal, siguiendo órdenes del duque apresó a unos cien individuos, y aunque las fuentes oficiales se refieren a gentes forasteras, de los alrededores, de íntima condición, como los principales agentes del tumulto, no tienen más remedio que admitir la participación de vecinos de la ciudad, y de hecho, en una carta enviada en octubre de 1392 al obispo de Valencia, don Jaime de Aragón, el monarca se quejaba ante su primo de

58 A.C.A., Cancilleria real, reg. 1961, fol. 46 r. 
que por parte de los oficiales eclesiásticos se ponían trabas para castigar a los culpables de los robos de Xàtiva y Alzira, al alegar algunos de los acusados ser tonsurados y ampararse en la jurisdicción eclesiástica para no ser juzgados por la autoridad civil, práctica que Juan I repudiaba no sólo por ir contra las regalías - pérdida de los beneficios económicos derivados del castigo del delito-y ser crimen de lesa majestad, sino porque servía de cobertura para ocultar otros muchos delitos, por lo que pedía que no se tolerara tal abuso ${ }^{59}$.

La realidad es que el rey no se preocupó hasta mucho tiempo después en aplicar justicia a los culpables. Más de un año después, el 2 de octubre de 1392, Juan I escribía a los justicias de Xàtiva, Alzira y otras villas del reino con judería (Orihuela, Alicante, Burriana, Villarreal, etc.) para que, bajo pena de 1.000 florines, colaboraran con el procurador real Fancesc d'Aguiló en el castigo de los culpables ${ }^{60}$. Se trataba de evitar las parcialidades, abusos y todo tipo de presiones a las que se veían sometidos estos funcionarios a la hora de castigar a sus conciudadanos, factores causantes en gran parte del retraso en la aplicación de justicia, y para ello la fórmula utilizada por Juan I fue la de nombrar procuradores especiales, cuya misión era asesorar al justicia criminal de Xàtiva, quien a su vez debía proceder con el consejo de cualquier letrado del reino - a condición, eso sí de ser imparcial-en los procesos criminales o civiles que se siguieran por tales sucesos ${ }^{61}$.

Un mes después, el 10 de noviembre, el monarca nombraba a Francesc d'Esplugues, caballero, y Antoni d'Alagón, licenciado en leyes, sus lugartenientes especiales para castigar a los implicados en los asaltos a las juderías del reino, pidiendo a todos los oficiales que les prestaran la ayuda necesaria ${ }^{62}$. Una carta del día 11 autorizaba a Francesc d'Esplugues a redimir por penas pecuniarias a aquellos participantes en el asalto de Xàtiva y Alzira que no quisieran esperar el juicio, respondiendo de las sumas percibidas a Berenguer de Cortilles, mercader de Zaragoza.

Parece que desde finales de 1392 Juan I está dispuesto a clausurar el tema de la judería de Xàtiva y todo el mecanismo punitivo, del que los nombramientos dichos formaban parte, se puso en marcha. A la vez, en noviembre de ese año, y para evitar que se produjera cualquier tipo de violencia contra los judíos, prohibió que en lo sucesivo en Xàtiva o en su

A.C.A., Cancilleria real, reg. 1925 , fol. $160 \mathrm{r}$.

A.C.A., Cancillería real, reg. 1925, fol. 133 r.

61 A.C.A., Cancilleria real, reg. 1924, fols. 109 v-110 r.

62 A.C.A., Cancilleria real, reg. 1924, fols. 115 v-116 r. 
justiciazgo ninguna persona pudiera llevar armas, sino tan sólo un cuchillo cuya hoja no sobrepasara la medida de un palmo. El que fuera encontrado culpable por el justicia o cualquier oficial sería ahorcado públicamente para memoria de los presentes y sus bienes confiscados por la corte, así como rotas las armas. De no cumplir los oficiales dicha orden perderían su oficio y serían castigados con una multa de 1.000 florines $^{63}$.

Y a principios de 1393, el 6 de enero, otorgaba plenos poderes a Roger de Moncada, gobernador del reino, y a Cerveró d'Alet, justicia de Xàtiva, para que en su nombre aplicasen justicia en aquéllos que fueran considerados culpables de participar en el saqueo de la judería ${ }^{64}$. Dos días después, ambos procuradores reales fueron autorizados a condonar dichos delitos por dinero, asesorándose en esta tarea por los jurados de la ciudad y otros prohombres ${ }^{65}$. De recaudar el dinero de tales multas en Xàtiva y su término se encargaron Ramón Sancho y Pere del Castellar, ciudadanos setabenses ${ }^{66}$.

Ya dijimos cómo, inmediatamente de producirse el asalto, el duque de Montblanch había ordenado al justicia de la ciudad que procediera contra los sediosos. Ello no fue posible llevarlo hasta sus últimas consecuencias, por la decisión de Juan I de querer intervenir personalmente en el castigo de los culpables en el reino de Valencia. Pero por aquellas fechas el rey estaba lejos, en Zaragoza. En el caso de Xàtiva se consideraba que ni la universidad ni el «Consell» eran culpables, y se achacaba lo sucedido, una vez más, a agentes foráneos, agentes de fuera de la urbe, pertenecientes a las clases inferiores.

Pero el rey, finalizada su estancia en el Principado de Cataluña y castigados los culpables de los asaltos a las juderías de Lleida, Barcelona y otras localidades se encontraba ya en el reino de Valencia y manifestó sus deseos de aplicar una rigurosa justicia con los culpables. Ante este propósito muchos vecinos de Xàtiva, incluso no culpables, se decía, temiendo que en medio del rigor fueran castigados los uno por los otros, justos por pecadores, se dispusieron a abandonar la ciudad con sus familias, lo que ya habían hecho algunos. Juan I era consciente del peligro que este hecho acarreaba, ya que como él mismo afirma, Xàtiva es una ciudad fronteriza (en realidad la frontera castellana estaba a medio centenar de kilómetros, pero era la plaza más importante de toda la comarca

63 A.C.A., Cancillería real, reg. 1924, fol. $115 \mathrm{r}$.

64 A.C.A., Cancillería real, reg. 1924, fols. $130 \mathrm{v}-131 \mathrm{r}$.

65 A.C.A., Cancillería real, reg. 1925, fol. 182 r.

66 A.C.A., Cancillería real, reg. 1904, fols. $153 \mathrm{r}-\mathrm{v}$. 
y su fortaleza era pieza clave en el sistema defensivo), por lo que, ante la amenaza de despoblación y con el consejo de la reina Violante, decidió perdonar a los habitantes de Xàtiva y su término, siendo castigados y expulsados de la ciudad una serie de individuos, que fueron considerados merecedores de dichas medidas por los jurados y prohombres. Se dio a las autoridades un plazo de tres meses para presentar la relación de los acusados, pasados los cuales no podrían hacerse modificaciones. El perdón se extendía también a los que atacaron a los moros y la morería de la ciudad -episodio del que no tenemos más datos, y que, según parece, no fue un temor sino una realidad-, siendo castigada cualquier autoridad que lo incumpliera con 2.000 florines $^{67}$.

En este perdón, una vez más y como sucedió en Valencia y otras localidades, jugó un papel esencial las necesidades financieras de la Corona, motivadas en este caso por el previsto pasaje del rey con una flota a Cerdeña para luchar contra Brancaleone Doria y otros rebeldes sardos, y en este caso la ayuda financiera de Xàtiva fue mayor que en ninguna otra ocasión ${ }^{68}$.

Como complemento del perdón real, el 18 de enero, en una carta dirigida a los notarios y escribanos de la corte de Xàtiva, Juan I les ordenaba el sobreseimiento de todos aquellos procesos contra los participantes en el asalto a la judería y su destrucción, incluso los originales ${ }^{69}$. La medida era incongruente y contraria al espíritu que animaba las anteriores intenciones del monarca. En realidad no creo que tuviera efecto, según se desprende de la carta del 12 de febrero enviada al gobernador del reino y al justicia de la ciudad para que procedieran a juzgar a los implicados en el asalto, pudiendo admitir penas pecuniarias como remisión ${ }^{70}$. Por otra parte, la existencia de los libros con el nombre de los asaltantes era una realidad, por cuanto que en junio de 1393 Juan I escribía a su depositario Pere Aldomar, notario, indicándole que debía entregárselos a los conversos de la ciudad, que se los habían solicitado al monarca, con el fin de poder emprender acciones judiciales civiles contra los culpables, a los que conocían con toda seguridad ${ }^{71}$. Lástima que ignoremos cuál fue el destino de estos libros, que habrían despejado todas las incógnitas que todavía plantea el asalto de Xàtiva.

67 A.C.A., Cancillería real, reg. 1904 , fols. $148 \mathrm{r}-151 \mathrm{r}$.

${ }^{68}$ A.C.A., Cancillería real, reg. 1904, fols. 151 r-152 r.

69 A.C.A., Cancillería real, reg. 1925, fol. $183 \mathrm{r}-\mathrm{v}$.

70 A.C.A., Cancilleria real, reg. 1924, fol. $141 \mathrm{r}$.

71 A.C.A., Cancillería real, reg. 1857, fol. 50 r. 
No sabemos cómo terminó el proceso contra los asaltantes, aunque por paralelismo con otros lugares, cabe pensar en un mínimo castigo para unas cuantas personas escogidas como culpables, como símbolo de todo el colectivo ciudadano. Lo que sí está claro es que los judíos llevaron la peor parte y se produjo la conversión masiva y forzada de los mismos, posiblemente al descenso del castillo, donde estaban refugiados. La vida de estos conversos no fue fácil en los primeros momentos, pues tuvieron que rehacer sus vidas y patrimonios, y muchos de ellos emprendieron la emigración clandestina, aun contraviniendo las órdenes reales. En 1393 Juan I los puso bajo su protección particular y les autorizó a ir libremente y residir por todos sus reinos. Un siglo más tarde, cuando la Inquisición española actúe sobre este colectivo vemos un total de 58 personas acusadas de judaizar, entre ellas el famoso médico Llúis Alcanyis. Serían los descendientes de los bautizados en 1391, cuyo total desconocemos. Pero el tema de los conversos forma parte de un estudio aparte.

\section{LA RECONSTRUCCIÓN DEL SIGLO XV}

En 1391 se produce una ruptura en el judaísmo de Xàtiva con la desaparición de su aljama y la conversión total o mayoritaria de sus miembros. A partir de ahora se inicia un nuevo proceso histórico que pasa por la restauración y consolidación de una nueva aljama y culminará con la extinción definitiva del judaísmo a raíz de la expulsión de 1492.

De nuevo volvemos a tener noticia de judíos en Xàtiva en un documento de 20 de marzo de 1393 en el que se alude a la aljama nuevamente creada («aljama noviter facta»), a la que se incorporarían las carnicerías de la antigua ${ }^{72}$. El problema estriba en saber si esta nueva aljama fue sólo una creación sobre el papel, un intento de reconstruir la judería setabense, similar al de Valencia, o se plasmó en una realidad y los judíos vuelven a instalarse en la ciudad desde finales del siglo xIV. Lo cierto es que las fuentes documentales no hacen más alusiones a esta nueva aljama.

Creo que el proyecto no pasó en estos momentos posteriores al asalto del terreno de las buenas intenciones y la judería de Xàtiva no vuelve a consolidarse hasta mediados del siglo XV. Hasta 1453 no aparece ningún documento con referencias a la aljama setabense. Ello no presupone que no hubiera judíos, pero sí que resulta indicador que todos los documentos

\footnotetext{
72 A.R.V., Real, 90, fol. 26 r-V.
} 
sobre judios en Xàtiva son de la segunda mitad de siglo, máxime cuando hay una continuidad cronológica y serial en las fuentes. Posiblemente el intento de rehacer la aljama no llegó a cuajar entonces, aunque poco a poco, una vez amortiguadas las tensiones por parte cristiana, y la política favorable a los judíos que se detecta a partir de Alfonso $V$ fueron atrayendo judíos a la ciudad -encrucijada económica de la zona y con una comunidad conversa, que puede servir de apoyo a sus antiguos correligionarios--. Este renacer se produjo a mediados del Cuatrocientos y el texto de 1453 es muy claro cuando alude a «los juehus qui son -ací venguts novament» ${ }^{73}$. En el futuro son habituales las expresiones «la juheria de la ciutat de Xàtiva» o «l'aljama de la juheria».

La reinserción de los judíos en la sociedad setabense debió reavivar viejas tensiones con los cristianos, aunque los signos que se detectan son a nivel particular. En 1453 se produjo una discusión entre un cristiano y un judío por cuestiones de juego, siendo apresado el hebreo por el justicia de la ciudad, que legaba tener jurisdicción sobre dicho individuo, según un fuero antiguo. El baile local, que consideraba lesionados sus derechos, escribió al baile general solicitándole consejo sobre qué hacer. Estas dudas del funcionario real permite sospechar que era el primer pleito que se planteaba entre miembros de las dos comunidades desde hacía tiempo, de ahí que la legislación estuviera casi olvidada. La respuesta, como era de esperar, hacía recaer el asunto en la jurisdicción real y no en la del justicia local, ya que los judíos, como es sabido, eran patrimonio real.

¿De dónde procedían estos nuevos judíos? Aunque no existe una mención explícita de su origen, creo que a través de sus apellidos y de sus actividades pueden obtenerse algunas conclusiones. Llama la atención, en primer lugar, la rareza de algunos de estos apellidos, que no los encontramos en otras juderías valencianas. Incluso hay algún nombre, como "Solimen» Sarmatisch, que sugiere la procedencia de algún país islamizado. Otro apellido como Malequí sugiere un origen malagueño, y es precisamente tras la consquista de Málaga por los cristianos en 1487 cuando se instalaría en Xàtiva, quizá ese año o en 1488, en que se documenta por primera vez. También el apellido Castillo sugiere un origen castellano. Pero lo más curioso, y quizá aquí se encuentre la respuesta a la pregunta arriba formulada, es ver cómo la mayoría de estos hebros de Xàtiva desarrollan preferentemente sus actividades mercantiles con los países musulmanes del Norte de África y el reino nazarí de Granada. Tal

73 A.R.V., Bailia, 1151 , fol. 769 r. 
es Abrafim Abenafí, que en 1476 va a comerciar a Almería, ciudad a la que también se dirigen ese año Enmanuel Bindo y Salomó Durán (1474, 1476), mientras que a Sicilia, Túnez, Argel y Berbería marchan Abraham Abenros (1469), Mossé Levi $(1474,1476)$, Jucef Abenros (1469), Maymó Zalmati, Salamó Zalmati (1467, 1469, 1474), Mossé Bencaydon (1474), Jucef Abenros (1469) y Salomó Durán (1474, 1476).

Que existían fuertes lazos económicos entre los judíos de Xàtiva y los del Norte de África es evidente, lazos que creo que eran también familiares - hecho habitual entre las comunidades hebreas de ambas orillas del mediterráneo-, pudiéndose pensar en una emigración y asentamiento de algunas familias judías norteafricanas, en particular de Túnez y la actual Argelia, hacia Xàtiva a lo largo de los años centrales de la centuria, reforzándose así los lazos comerciales entre Valencia y los Estados del Norte de África.

Pero la apertura hacia otros países mediterráneos no alejó a los hebreos setabenses de sus correligionarios del reino de Valencia. Las relaciones con otras aljamas, en particular la de Sagunto, la más dinámica, eran frecuentes. En 1468, a instancias de los adelantados de la aljama saguntina, el baile general requería a los adelantados de Xàtiva para que comparecieran en su corte a fin de resolver las diferencias existentes entre ambas aljamas ${ }^{74}$.

Otras veces los contactos eran amistosos y en 1481, por ejemplo, vemos como el baile general del reino otorgó guiaje al judío setabense David Nagari, a instancias de Salamó Saporta, de Sagunto, para poder viajar por todo el reino ${ }^{75}$. En 1492 el baile general notificaba a Samuel Castillo, de Xàtiva, que por Nicolau Ferrer, procurador de Mossé Assé, de Sagunto, le fue mostrada una sentencia dada en febrero de ese año entre ambos judíos por la que Castillo debía pagar 15 libras a Mossé o a Jaffuda Jabba en razón de cierto violario en la sentencia especificado ${ }^{76}$.

En el tercer cuarto de siglo Xàtiva aparece como la segunda judería del reino, llena de vitalidad. Las famiiias más dinámicas parece que fueron los Zalmatich (Sarmati, Zalmati, Salmatich), Malequí y Castillo, todas documentadas en esta segunda mitad de siglo. Mantenian intensos contactos comerciales con el Norte de África y negociaban con seda local, como la que vendió en 1475 Salamó Zalmatich a Magaluf Guetdeix, judío de Tremecén que había venido a Valencia en las galeras venecianas ${ }^{77}$.

74 A.R.V., Bailia, 1154, fol. 217 v.

75 A.R.V., Bailia, 1157, fol. $139 \mathrm{v}$.

76 A.R.V., Bailia, 324, fol. 344 r.

${ }_{77}$ A.R.V., Bailia, 1296, fol. 192 r. 
Maymó Zalmati (1461) era el padre de Salamó Zalmati, el judío setabense más documentado, que lo mismo viaja a Túnez que sale como fiador de sus compañeros o se asocia con un moro para la búsqueda de metales preciosos. Un primo hermano suyo lleva también el mismo nombre, siendo otros presuntos miembros de la familia: Salomó Sarmatich (1475), Solimán Sarmatich (1475) y Benahem Sarmatich (1475), que en el momento de la expuisión era el rabino de Xàtiva. Que la posición socioeconómica de sus miembros era elevada lo prueba el que Maymó Zalmati, posible jefe familiar, poseyera varios cautivos. En 1461 vendió a Joan Roiç Domenech un cautivo negro guineano y otro negro a Pere Siurana por 76 libras, 10 sueldos, esclavos que el baile le había concedido de su propiedad $^{78}$. Ese mismo día abona al Maestre Racional 60 sueldos como derecho del quinto por las 45 libras en que le fueron valorados dos esclavos negros comprados en una subasta ${ }^{79}$.

Entre las actividades desempeñadas por los judíos de Xàtiva la comercial sería la más importante. Comerciaban dentro del propio reino, acaparando posiblemente Valencia la mayoría de ese tráfico. En 1473, seis judíos setabenses que se dirigían a comprar mercancías a Valencia fueron atacados en el paraje de los Algadins por cinco hombres que les robaron y secuestraron a cuatro de ellos, lo que motivó una orden de búsqueda y captura contra los malhechores por parte del baile gene$\mathrm{ral}^{80}$. A veces se servían de moros traginers para el transporte de mercancías, según se ve en el pleito entablado entre Menahem Zalamari y dos moros contratados para traer desde Valencia dos "canffes" (?), que no llegaron a su destino, reclamando el judío los correspondientes daños ${ }^{84}$.

La participación en el comercio exterior fue destacada, en particular a partir de finales de la década de los sesenta, orientándose, como ya dijimos, hacia el Norte de África y Granada. En 1476, por ejemplo, los cinco salvoconductos concedidos para viajar por el baile general a judíos valencianos, lo fueron todos a residentes en Xàtiva. A la capital de la Costera acudían también hebreos de la otra orilla del Mediterráneo, como atestigua un texto de 1475 en el que dos judíos de Berbería acompañados de Salamó Zalmatich, de Xàtiva, reclamaron a Joan Dalmau 40 reales que les debía por una piel berberisca ${ }^{82}$. Es posible que algunos judíos extendiesen el radio de acción de sus negocios a localidades próximas, como

\footnotetext{
A.R.V., Maestra racional, 71, fol. 172 v.

A.R.V., Maestre racional, 71, fol. 172 v.

A.R.V., Bailia, 1155 , fol. 31 v.

A.R.V., Bailia, 1155, fol. $394 \mathrm{r}-\mathrm{v}$.

A.R.V., Bailia, 1296, fol. 99 v.
} 
Samuel y Mossé del Castillo, setabenses, pero residentes en la vecina Alzira, carente por entonces de aljama.

De otras profesiones ejercidas por los judíos la única documentada es la de sastre, por un tal Çacon Homar. Sabemos que se dedicaban al comercio de la seda, sin que podamos precisar si participaban en la industria sedera - si es que la hubo en la ciudad en esas fechas-.

No desdeñaron los hebros de Xàtiva relacionarse con los musulmanes, incluso en negocios comunes. $Y$ así vemos que en 1473 el baile general autoriza a Salamó Zalmatich y a Acen Catim, moro de Bechí, a que juntos pueden buscar "tresors", "es a saber: or, argent, pedres precioses, perles e altres qualsevol joyes 0 metals" ${ }^{83}$. Aunque no siempre los negocios marcharon bien, y en 1479 Alí Cortés, moro de Pedrola (Zaragoza), debe dejar a un hijo suyo de siete años como prenda de una deuda de 50 libras que tenía con el arriba citado Çacon Homar, hasta cancelarla ${ }^{84}$.

Constituidos en aljama, como él en pasado, los judíos setabenses abonarían en esta centuria sus impuestos al monarca, en un montante que ignoramos. Sólo sabemos que en 1477 con motivo de la boda de la infanta Juana, hija de Juan II de Aragón, con Fradrique de Sicilia, la judería de Xàtiva entregó al Maestre Racional 110 sueldos que le correspondían por el "dret del maridatge", la mitad de lo que tributó la aljama de Sagunto, lo que nos proporciona una pista indirecta sobre la importancia y tamaño de la aljama de Xàtiva, que podemos calificar de tipo medio, detrás de la de Sagunto y por delante de otras juderías menores, como la de Castellón, que sólo contribuye con 33 sueldos.

Respecto al marco físico en el que desenvuelven su vida cotidiana los judíos en este siglo, el principal problema lo plantea la ubicación de la judería, comenzando por no poder afirmar con certeza que existiera una continuidad del hábitat judío anterior a las violencias de 1391. Ningún testimonio hace referencia al lugar donde residían los judíos y en principio podemos suponer que siguieran viviendo en el recinto tradicional.

Lo único cierto es que los judíos tenían sus carnicerías en el arrabal de "Les Barreres", fuera de la muralla de la ciudad, según un privilegio otorgado por Pedro III. La carnicería limitaba con casas a Macià Dasí, por un lado, y por el otro con la calle que conducía a la iglesia de Sant Miquel, y en la parte delantera con la plaza que conduce a la Morería ${ }^{85}$. En 1487

\footnotetext{
83 A.R.V., Bailia, 1155 , fols. 54 v-55 r.

84 A.R.V., Bailía, 1156 , fol. 409 v.

85 A.R.V., Real, 307 , fols. 81 v-82 r.
} 
Fernando ll ordenó que los judíos sacrificaran y cortaran en ella obligatoriamente sus reses.

El 31 de marzo de 1492 Fernando e Isabel firmaron el edicto que ordenaba la salida de sus reinos de los judíos, lo que, como es obvio afectaba a los judíos de Xàtiva. El tema lo he analizado con detalle para el conjunto del reino de Valencia ${ }^{86}$, por to que ahora nos referiremos al caso de Xàtiva.

Como en todas partes dado lo inesperado y la premura de tal disposición a los judíos se les plantearon numerosos problemas, sobre todo de tipo económico, que son los que nos han dejado algunas noticias. Los internos, la angustia y la desesperación que debió germinar en el interior de cada ser, eran patrimonio personal, íntimo. Las aljamas y los particulares tuvieron que liquidar sus patrimonios y cancelar sus deudas. Las noticias conservadas de los judíos valencianos son tardías, del mes de julio, es decir pocos días antes de la fecha de partida prevista, el 1 de agosto. Sabemos, por ejemplo, que el 25 de junio Benahem Salmatich, que era la cabeza visible de la aljama y su rabino, abonó al baile general la suma de 12 libras, 10 sueldos, a Cristòfol Vassurto, oficial de la bailía, 25 libras, a Francesc de Sent Feliu otras 12 libras y al alguacil de la bailía 12 libras, 10 sueldos recaudados entre los hebreos ${ }^{87}$, posiblemente en virtud de un acuerdo entre las partes para la concesión de los correspondiente guiajes y permisos de partida.

El 9 de julio Benahem Salmatich y Salomó Durán cancelan una cuenta de 101 libras, dos sueldos, seis dineros, de aquella suma que habían recaudado entre los judíos de la ciudad por orden del gobernador y del justicia local ${ }^{88}$.

Los judíos de Xàtiva partieron hacia el destierro por el puerto de Morvedre (Sagunto). Los contratos de embarque se hicieron bien a título individual o bien colectivo. En el primer caso nos ha llegado el contrato firmado por el judío Salamó Malequí, cuyo potencial económico le permitió fletar por su cuenta la carabela de mossén Antoni Joan, caballero de Valencia, el 22 de junio de 1492. El contrato es similar a cualquier otro en sus aspectos generales: la embarcación estará bien aparejada, armada, con 40 hombres capaces para su control y defensa. El buque estaba surto en la atarazana de Valencia, comprometiéndose a partir desde ese mismo

86 Hinojosa Montalvo, J., "Solidaridad judía ante la expulsión: contratos de embarque (Valencia, 1492)», Saitabi, n. ${ }^{\circ}$ XXXIII, 1983, págs. 105-124.

87 Archivo Municipal de Alcoy, Protocolos de Pere Benavent, 1490-1492, sin fol., 25-6-1492.

88 ARChivo Municipal. de Alcor, Protocolos de Pere Benavent, 1490-1492, sin fol., 9-7-1492. 
día al próximo 10 de julio. En ese plazo Malequí podría cargar o descargar lo que quisiera. Desde el Grau de Valencia partiria hacia Sagunto, donde haría escala durante tres días, pudiendo cargar o descargar lo que quisiera, para desde aquí dirigirse hacia Orán, Bugía, Argel o Tenés, en uno de cuyos puertos, el que prefiriera, estaría ocho días, desembarcando él y lo que quiera de las mercancías que transporte. Si superaba la estancia los ocho días pagaría un suplemento diario de cuatro ducados de oro. A continuación la carabela regresaría a Valencia. El flete se estipulaba en 300 ducados, o su valor en mercancías, libres de los impuestos de Bebería. El flete o la mercancía la abonaría en Valencia.

Por su parte Antoni Joan promete al judío darle una fianza de 600 ducados por las mercancías que compre y que serán transportadas en la carabela, aunque viajarán a riesgo de Malequí, que será el encargado de asegurarlas. Antoni Joan gestionaría su venta una vez hubieran llegado al puerto de destino. Entre los testigos del contrato aparece Abraham l'Astruch, judío de Teruel ${ }^{89}$. Podemos imaginar el drama personal de gentes como el tal Malequí, de posible origen malagueño, como se deduciría de su apellido, y que había emigrado a Xàtiva tras la caída de su ciudad natal en poder cristiano (1487), y ahora a los pocos años de rehacer su vida se ve forzado a una nueva emigración, esta vez definitiva. Pero tenía la suerte de disponer de un capital con el que emprender una nueva vida a la otra orilla del Mediterráneo. Otros no serían tan afortunados. No sabemos si hubo más contratos de embarque de judíos setabenses a título personal.

En los contratos colectivos, de juderías aragonesas o valencianas, desempeñaron un papel muy importante los conversos valencianos, que actuaron con intermediarios o gestionaron dichos contratos en nombre de sus antiguos correligionarios, con los que mantenían en muchos casos lazos comerciales y de amistad. El 7 de mayo de 1492 se firmó el contrato de embarque entre los judíos de Sagunto y Xàtiva, las dos principales colectividades hebreas del reino, con Bernardo Franquis y sus hermanos, importantes mercaderes genoveses que operaban en Valencia, así como con Jaume Marga, mercader de Valencia. Por parte de los judíos setabenses, que son los que ahora nos interesan, actuaron como procuradores Abraham Abendavid, Mahiz Alpegri (Alpegui), Mossé Abenzaydon, Yucef Capaço, Salamó Castelli (en otro lugar lo cita como Jacob Castell), Mossé Almcarem, Gento Cohen, Yucef Cohen, Salomó Durán, en su nom-

89 A.R.V., Protocolos notariales, Jaume Salvador, 2009 , fol. 315 r-317 r. 
bre y en el de los adelantados y consejero de la aljama. La procura les fue confiada en Xàtiva el 5 de julio ante el notario Francesc Montfort.

Los genoveses y el valenciano se comprometen a entregar a los judíos de Sagunto y Xàtiva la nave de micer Francisco de Grimaldis, genovés, con un porte de 25.000 quintales, u otra nave similar, aparejada y armada con unos 100 hombres. La nave estaría en la playa de Sagunto el 20 de junio próximo, pudiendo cargar las ropas y mercancías acordadas. Si la nave permaneciera más allá del 10 de julio, abonaría por cada día de más la suma de 20 ducados.

La nave cargaría 1.000 personas, aunque se podría aumentar hasta 50 más. Pero si el patrón decidiera que admitía otras 500 personas, que pudiera hacerlo, hasta totalizar 1.500 personas. 25 niños de pecho estaría libres del pago del flete. Los judíos podrían cargar las ropas que quieran, siempre que las partes se pongan de acuerdo en los derechos a abonar, ya que de no hacerlo se elegiría para arbitrar la diferencia de Galcerán Adret, mercader de Valencia (y converso).

Una vez embarcadas las personas y mercancías la nave partiría sin escalas hacia Pisa, donde harian una escala de ocho días, para desembarcar las personas y mercancías que quisieran. Luego seguiría hacia Nápoles, con otra escala similar de ocho días. En el caso de que los genoveses prohibieran el atraque en Pisa, en tal caso lo harían en Civitavechia.

Los judíos podrian cargar las botas de agua necesarias para la travesía, habiéndolas depositado previamente a la orilla del mar, donde las llenaría el patrón. La custodia y distribución del agua quedaba en manos judías. El mismo procedimiento se seguiría con la leña, vino y vituallas que necesitaran para el viaje. Los judíos no pagarían por sus personas, útiles, muebles de casa y libros el derecho llamado "strazeto", y de las mercancías abonarian lo que era habitual entre los extranjeros en naves de genoveses, según la costumbre de éstos. Podrían subir a la nave las armas que quisiera, quedando bajo la custodia del patrón, siéndoles devueltas cuando desembarquen sin pagar ningún flete.

Si durante la travesía surgían diferencias ente los judíos, el patrón no se inmiscuiría, salvo que fuera llamado como árbitro, o en el caso de que llegaran a las manos, en cuyo caso el patrón debía intervenir.

El flete acordado fue de tres ducados por persona, salvo los niños declarados exentos. Abonarían de inmediato 1.500 ducados y el resto tres días antes de embarcar. Si hubieran gastos por causa de correos, los hebreos sólo pagarian 50 ducados, corriendo el resto a cuenta de los hermanos Franquis y de Jaume Marga. Dicha suma han de abonarla en 
aquel momento. Por su parte el patrón presta juramento - personalmente - mediante delegado si no quería salir del barco- de llevarlos al lugar pactado, defenderlos y no engañarlos. Los fletadores se comprometían a que en el caso de que los judíos necesitaran fletar otras naves para llevarlos a estos destinos, ellos correrían con todos los gastos que superaran la cantidad estipulada. Si los judíos no quisieran o no pudieran partir abonarían los fletes de vacío, como si hubieran hecho el viaje, comprometiéndose los Franquis y Marga a transportar en la nave mercancías que pesaran el equivalente a las citadas personas que debían haber embarcado. El contrato sería notificado, en Valencia o en Sagunto, a los judíos para ver si lo aceptaban o no, teniéndolo por firme una vez notificado.

El Estado exprimió todo lo que pudo a los judíos, quienes tuvieron que pagar una tasa de partida, que en el reino de Valencia fue evaluada en cinco sueldos por persona. Hasta el último momento siguieron siendo para el fisco de «nostre tresor». La cantidad recaudada nos permite hacer una evaluación bastante ajustada del número de judíos que se embarcaron, que en el caso de Xàtiva fue de 248. La aljama de Sagunto, la cabeza del judaísmo valenciano, contaba con 700 personas. Xàtiva, por tanto, aparece en el momento de la expulsión como una judería plenamente consolidada, dinámica, la segunda del reino. Todo se vino abajo el 1 de agosto, cuando sus moradores tuvieron que partir hacia el destierro, hacia el Norte de África o Italia. Un nuevo capítulo en sus vidas, plagado de incógnitas, se abría ante ellos. Una parte de la historia del reino de Valencia quedaba también truncada. 